\title{
Apuntes para el estudio de la jurisdicción monástica en la Galicia medieval: renta señorial, sujeción a la tierra y justicia (siglos X-XIII)
}

\author{
José Antonio López Sabatel ${ }^{1}$
}

Recibido: 14 de setembro 2018 / Aceptado: 31 de xaneiro de 2020

Resumen. El objetivo de este artículo es someter a escrutinio los típicos derechos jurisdiccionales bajo los que el campesinado gallego vivía y ejercía sus labores. Con el fin de obtener una muestra de la evolución de estos privilegios, se han examinado los fondos documentales de hasta trece monasterios. De este modo, los más característicos tipos de prestaciones señoriales, la adscripción a la tierra y el ejercicio de la justicia serán, abordados en las siguientes líneas, siempre teniendo en consideración sus orígenes, su esencia, desarrollo y, por lo tanto, su impacto en el día a día de la sociedad campesina.

Palabras clave: Galicia; Edad Media; campesinado; señorío monástico; derechos jurisdiccionales.

\section{[gal] Apuntamentos para o estudo da xurisdición monástica na Galicia medieval: renda señorial, suxeición á terra e xustiza (sécs. X-XIII)}

Resumo. O obxectivo deste artigo é someter a escrutinio os típicos dereitos xurisdicionais baixo os que o campesiñado galego vivía e exercía os seus labores. Co fin de obter unha mostra da evolución destes privilexios, examináronse os fondos documentales de ata trece mosteiros. Deste xeito, os máis característicos tipos de prestacións señoriais, a adscrición á terra e o exercicio da xustiza, serán abordados nas seguintes liñas, sempre tendo en consideración as súas orixes, a súa esencia, desenvolvemento e, polo tanto, o seu impacto no día a día da sociedade campesiña.

Palabras chave: Galicia; Idade Media; campesiñado; señorío monástico; dereitos xurisdicionais.

[en] Notes for the Study of the Monastic Jurisdiction in Medieval Galicia: Seigneurial Income, Family-land Bond and Justice (10th-13th centuries)

\begin{abstract}
The aim of this paper is to scrutinise the typical jurisdictional rights under which the Galician peasantry used to live and was required to work. For this purpose, the cartularies of thirteen monasteries have been examined in search of the best possible sample of the evolution of these privileges. And thus, the most characteristic kind of seigneurial income, attachment to the land and exercise of justice will be addressed in the following lines, taking into account their origin, essence, development and, therefore, their impact on the daily life of peasant society.
\end{abstract}

Keywords: Galicia; Middle Ages; Peasantry; Abbatial Lordship; Jurisdictional Rights.

Sumario. 1. El coto jurisdiccional y el señorío. 2. La sujeción a la tierra. 3. La jurisdicción y el foro. 4. Obligaciones jurisdiccionales: servicio, foro, derechura, luctuosa. 5. La Justicia. 6. Conclusiones. 7. Referencias bibliográficas.

Como citar: López Sabatel, J. A. (2020): “Apuntes para el estudio de la jurisdicción monástica en la Galicia medieval: renta señorial, sujeción a la tierra y justicia (siglos X-XIII)", en Madrygal. Revista de Estudios Gallegos 23, pp. 215-222.

1 Universidad Nacional de Educación a Distancia. Departamento de Historia Medieval y Ciencias y Técnicas Historiográficas.

Correo-e: jlopezsa13@gmail.com; https://orcid.org/0000-0002-5280-0961. 
Con el fin de examinar los condicionantes socioeconómicos de la Galicia medieval es necesario adentrarse en el universo de relaciones interpersonales que nacen en los dominios señoriales entre las entidades monásticas y el campesinado que bajo su autoridad nacía, trabajaba y moría. Partiendo del origen, causa y esencia misma de este poder jurisdiccional se examinará, a continuación, la inherencia de unos lazos firmes, pero a la vez desiguales; vínculos, estos, de naturaleza más sociopolítica que estrictamente económica que, básicamente, tomaron forma de prestaciones y de un férreo sometimiento del individuo a la tierra que cultivaba. Sin embargo, la jurisdicción no se reducía simplemente a la recaudación de exacciones y al control de la población, también era inherente a la administración de la justicia.

Para el análisis del ejercicio de estas prerrogativas me he basado en referencias sustraídas de los fondos de diferentes entidades monásticas pertenecientes a diversas órdenes religiosas convencido de que la revisión de un mayor volumen documental contrarrestaría, de alguna manera, las posibles restricciones temporales y geográficas que pudiesen menoscabar la obtención de información de interés ${ }^{2}$. El examen de este amplio espectro heurístico ha sido en gran medida facilitado por la ya existente transcripción y publicación de los tumbos y colecciones cuyo contenido documental constituye el soporte indispensable para sustentar este estudio $^{3}$. Esta procedencia tan heterogénea tanto en lo relativo a la adscripción como a la localización de los monasterios pretende dotar al artículo de una información cuya amplitud y variedad esté en consonancia con el eclecticismo propio de cualquier análisis que aborde el desarrollo del señorío monástico gallego.
Un análisis que ha gozado de gran protagonismo en la historiografía gallega de los últimos cuarenta años. Así, las décadas de los setenta y ochenta ven florecer una emergente fascinación por el mundo agrario, en mayor medida encauzada por un mismo hilo conductor, esto es, el estudio de los dominios monásticos como marco geográfico ideal donde asentar una nueva perspectiva metodológica dirigida a esclarecer nuevas preocupaciones relativas tanto a las estructuras agrarias y señoriales como a la organización social del espacio y sus gentes. De este modo, nuevos temas de estudio tales como el régimen de propiedad, la naturaleza de las explotaciones y las características de las tenencias, los contratos agrarios, la modificación del paisaje, las prácticas agrícolas y los cultivos, la formación de patrimonios señoriales y el establecimiento de lazos de dependencia, las relaciones socio-jurídicas entre señores y vasallos, los conflictos sociales, la distribución de la población y los diferentes modelos de hábitat, etc., fueron abordados de forma exhaustiva sobre bases geográficas de carácter local o regional. En lo relativo al caso gallego, cinco fueron los trabajos que vieron la luz entre 1971 y 1983, siendo aún hoy en día de obligada referencia para cualquier historiador interesado en los diversos espacios señoriales gallegos; estos son: El Bajo Valle del Miño en los siglos XII y XIII: economía agraria y estructura social (1971), de María del Carmen Pallares Méndez y Ermelindo Portela Silva; $L a$ región del obispado de Tuy en los siglos XII al $X V$ : una sociedad en la expansión y en la crisis (1976), de Ermelindo Portela Silva; Señores y campesinos en Galicia: siglos XIV-XVI (1976), de María Xosé Rodríguez Galdo; El monasterio de Sobrado: un ejemplo de protagonismo monástico en la Galicia Medieval (1979), de

2 Se hace necesario subrayar, sin embargo, las notables diferencias en cuanto al volumen documental producido hasta el siglo XIII por los monasterios aquí examinados. Así, por ejemplo, del monasterio de Celanova, solamente datados entre los siglos IX y XII, se conservan 586 documentos, mientras que, de los también benedictinos masculinos de San Xiao de Samos, San Vicenzo de Pino, San Xiao de Moraime, San Martiño Pinario, Santo Estevo de Ribas de Sil y San Vicenzo de Pombeiro para la cronología de este estudio (siglos X-XIII) han llegado hasta nosotros 404 .

3 Estas instituciones son las que siguen: Santa María de Sobrado dos Monxes (cisterciense) ; San Salvador de Celanova (benedictino masculino); San Xiao de Samos (benedictino masculino); San Miguel de Bóveda (benedictino femenino); San Martíño de Xubia (cluniacense); San Vicenzo de Pino (benedictino masculino); Santa María de Oseira (cisterciense); San Vicenzo de Pombeiro (benedictino masculino); San Clodio do Ribeiro (cisterciense); San Martíño Pinario (benedictino masculino); Santo Estevo de Ribas de Sil (benedictino masculino); San Xoán de Caaveiro (agustino); San Pedro de Vilanova de Dozón (benedictino femenino); San Xiao de Moraime (benedictino masculino); Santa María de Melón (cisterciense). La relación de las diferentes ediciones correspondientes al corpus documental de estos monasterios se puede hallar en la bibliografía al final de este estudio. 
María del Carmen Pallares Méndez; y, por último, Señorio de Santa María de Meira (de 1150 a 1525): espacio rural, régimen de propiedad y régimen de explotación en la Galicia Medieval (1983), de Dolores Mariño Veiras. Si bien es cierto que durante la década posterior se puede apreciar un gran apego por el mundo monástico, como no puede ser de otra manera en Galicia, no lo es menos que esta inclinación, al igual que sucedió en épocas pretéritas, se postula más orientada al cenobio en sí mismo y a su organización que a la población que vivía y moría bajo sus dominios (Portela Silva y Pallares Méndez 1993: 83). Desde los noventa hasta nuestros días no han faltado estudios dirigidos hacia la recuperación del análisis del señorío monástico siempre en consonancia con la impronta dejada por el mismo en la sociedad y en el territorio circundante (Pastor de Togneri 1990). En este periodo han sido muchas las monografías publicadas que adoptan esta temática ${ }^{4}$, aunque tres estudios destacan por recoger el testigo de la labor iniciada en los setenta, observándose en todas ellas una gran fidelidad hacia los parámetros metodológicos fijados por Pallares Méndez y Mariño Veiras en sus respectivos estudios sobre los señoríos monásticos de Sobrado y Meira (Pérez Rodríguez 1996).

En cuanto al marco temporal de este estudio he elegido aquel que coincide en su inicio con las primeras manifestaciones escritas que fundamentan el examen de la materia a tratar y que culmina con el predominio en el campo gallego de la explotación indirecta en detrimento de la directa. No obstante, creo oportuno matizar en este punto que, debido a la complejidad y a la amplia cronología inherentes al presente objeto de estudio, las siguientes líneas solo pretenden establecer una primera aproximación histórica que pueda llegar a asentar los fundamentos esenciales sobre los que erigir, en un futuro próximo, un más dilatado análisis histórico encaminado a llamar a la reflexión sobre la jurisdicción monástica en la Galicia medieval.

\section{El coto jurisdiccional y el señorío}

Uno de los elementos básicos sin el cual no se llegaría a entender el proceso feudalizador de la Europa medieval es el que hace referencia a la inmunidad como factor clave de la disgregación del poder público ejercido por el monarca. En lo relativo a las entidades monásticas objeto de este estudio, decir que las concesiones de naturaleza jurisdiccional bajo la fórmula de privilegio de coto parecen, como no podía ser de otra manera, seguir una pauta común en toda Galicia por la cual no se explicita la palabra coto hasta la generalización del término en $1095^{5}$, sin que, por ello, sufriesen menoscabo en modo alguno los derechos y atribuciones que acompañaban a estas entidades territoriales (Bermúdez Beloso 2017: 88). De este modo, el texto más madrugador corresponde a los fondos del monasterio de Samos, ya que, en 811, Alfonso II le concedió el radio de milla y media que circunvalaba la abadía de san Xián (Lucas Álvarez 1986: doc. 36). A lo largo del siglo posterior son cuatro los cenobios que se vieron privilegiados por el monarca. Así, Ribas de Sil en 921 recibió de Ordoño II gran número de posesiones (Duro Peña 1977: doc. 1) y Sobrado dos Monxes fue dotado en 958 por Ordoño IV con el condado de Présaras (Pallares Méndez 1979: 98). Como arriba ya se señaló en ningún caso se menciona el término coto, tampoco se haría en las concesiones reales de Bermudo II, primero a Celanova (986) y después a Pombeiro (997), sin embargo, en estas últimas parece evidente la presencia de autoridad pública; en el primer caso, con el poder otorgado sobre los hombres de Caldelas y Taiberós (Andrade Cernadas 1995: doc. 5), en el segundo, con la inmunidad sobre el territorio (Lucas Álvarez y Lucas Domínguez 1996b: doc. 3).

Habrá que adentrarse en el siglo XII para testimoniar la palabra coto de forma generalizada en la documentación. La primera es apócrifa de $1007^{6}$, un año inviable para que Alfonso VII extendiese tal privilegio al territorio en el que estaba asentado el monasterio

4 Con el fin de obtener más información sobre esta producción historiográfica, de especial interés son las lecturas de Pérez Rodríguez 2008a y Pérez Rodríguez 2008b: 322-330.

5 Antes de esta fecha e, incluso más allá de la misma, no es improbable que los documentos por los que se conceden privilegios de coto sean una falsificación o estén interpolados. Un caso paradigmático es el apócrifo privilegio de coto concedido en 929 al monasterio de Calogo (García Álvarez 1973: 258-263). Para profundizar en la crítica textual sobre originales y falsos en los fondos conservados es de sumo interés Díaz Salvado 2011.

6 O 1107 tal como aparece en la data recogida por Sánchez Belda en el Archivo Histórico Nacional (1953: doc. 182). 
de Caaveiro ${ }^{7}$. La segunda, diez años después y, también dirigida a esta institución, auténtica, la tercera, de ese mismo año (1117) interpolada con el fin de ampliar en un cincuenta por ciento los lindes jurisdiccionales del cenobio (López Sangil 2006: 174-177). No hay duda que Alfonso VII fue un monarca recurrente en los tumbos, cuya presencia se corresponde con la cesión de cuotas autoridad pública hacia distintas instituciones monásticas gallegas (Pousa Diéguez 2018: 179-180). Tal prodigalidad es constatable en los fondos de Moraime (Benlloch del Río y Pensado 2015: 27-29), Oseira (Romaní Martínez 1989: doc. 15) ${ }^{8}$, Pino (Monforte) (Vázquez 1990: 162; Rodríguez Fernández 1991: doc. 3)9 ${ }^{9}$, Pombeiro (Lucas Álvarez y Lucas Domínguez 1996b: doc. 7), Samos (Lucas Álvarez 1986: doc. 57; Arias Cuenllas 1992: 134) y Dozón (Fernández de Viana y Vieites 2009: doc. 18) ${ }^{10}$, instituciones, todas ellas, beneficiadas por una línea de actuación que, en lo concerniente no solo al mencionado Samos (Lucas Álvarez 1986: docs. 117 y 135), sino también a San Martiño Pinario (Lucas Alvarez, 2003: docs. 74 y 77) y Bóveda (Fernández Fernández 2005: doc. $1)^{11}$, tuvo precedente en su madre Doña Urraca mientras que, en lo relativo a Xubia, mostró clara continuidad por parte de su hijo Fernando II (Montero Díaz 1935: doc. 82). Una de las razones políticas más aceptadas para explicar este proceder real, no es otra, que la carencia por parte de la monarquía de un aparato burocrático, lo suficientemente sólido y efectivo, como para garantizar el control sobre un territorio de retaguardia relegado a un segundo plano ante los avances de la reconquista y la prioridad de una organización inmediata de las zonas recién anexionadas. Para tal fin y, conseguir este propósito, el rey decidió apoyarse tanto en la aristocracia local como en las instituciones eclesiásticas ${ }^{12}$. No es de extrañar que, durante el siglo XIII, coincidiendo con el fortalecimiento de la Corona y el parón de la Reconquista, se produjese un cese generalizado en la concesión de privilegios de coto (Fernández Casal 1995: 79-80).

Sería Sánchez Albornoz, quien resumiese las prerrogativas adquiridas por el inmunista: derecho de percibir tributos y servicios de naturaleza real, administración de la justicia y cobro de multas, y en último término, el mantenimiento del orden público, la atribución de exigir fonsadera y la organización de la hueste (1976: 1281 y ss.). De modo que los sayones reales a causa de tal inmunidad se veían impedidos a adentrarse en espacio acotado por razones de homicidio y rauso (Sánchez Belda 1953: doc. 137); homicidio, rauso y fossataria (Andrade Cernadas 1995: docs. 6 y 29) y omicidio, rausso, fossataria, annutuиa у qualequmque suposita mala (Sánchez Belda 1953: doc. 160). Así pues, el señor, a través del coto, se garantizaba un estrecho control que excedería el mero dominio eminente ejercido sobre sus propiedades y siervos, extendiéndose sobre todo hombre libre, propietario o colono, que al vivir y morir en su jurisdicción se fue convirtiendo así en su vasallo (García de Valdeavellano 2000: 131). En consecuencia, y teniendo en cuenta el estado generalizado de inseguridad propio de los primeros pasos de la monarquía astur-leonesa, se fue haciendo paulatinamente más necesaria, con el fin de garantizar la productividad de la propiedad dominical, una clara identificación entre ésta y los poderes políticos cedidos por el soberano (Sánchez Albornoz 1976: 1285). De hecho, desde el siglo XI esta armonización entre propiedad y jurisdicción se formularía como elemento vital en la articulación de un nuevo espacio de poder: el señorío (Martínez García 2008: 24), mecanismo de extracción de renta que no se puede entender sin la estrecha relación existente entre el derecho dominical sobre la tierra y el gobierno sobre los hombres (Clavero 1975: 116). Es por

El texto es una falsificación realizada posiblemente en los últimos años de reinado del emperador (Díaz Salvado 2011: 410).

Este autor da el documento como auténtico. Sin embargo, Rassow (1928: 430) afirmó que es falso.

El documento editado es una copia del siglo XVIII.

Documento que, pese a haber sido tildado de "sospechoso de falsedad", el autor lo considera como auténtico.

Copia simple en el Tumbo de San Clodio del siglo XVII de un traslado anterior realizado en septiembre de 1207.

12 Una política esta de larga tradición en lo que respecta a Galicia, remontándose al siglo IX y consistente en la siguiente reciprocidad: legitimación por parte de la monarquía de la propiedad y jurisdicción cedidas a cambio de control efectivo, organización del territorio y sacralización de la autoridad real por parte de los diferentes poderes eclesiásticos (Portela Silva 2009: 221). Para una mayor profundización en el estudio de las relaciones de poder entre la alta nobleza gallega y el rey Alfonso VII, véase Vital Fernández 2011 y 2016. 
ello que para algunos autores hablar de señorío jurisdiccional no es más que una redundancia, ya que, en último término, es la jurisdicción la que define al señorío, negándose la existencia del segundo sin la presencia de la primera (Colás Latorre 1993: 64).

El coto, como primigenio centro neurálgico del poder señorial reunió una serie de rasgos característicos dignos de destacar. Uno de ellos, el relativo a su extensión, es partícipe de una tendencia continuista común en el periodo altomedieval. Del mismo modo que el condado en su faceta de nuevo centro administrativo se circunscribió, en la mayoría de los casos, al antiguo trazado comarcal o Territoria preexistente (López Carreira 2008: 21) y la actual red parroquial hizo lo propio con las antiguas villae (Pallares Méndez y Portela Silva 2007: 66), muchos municipios y parroquias del presente no han sido más que prolongaciones temporales, en cuanto sus dimensiones, de los antiguos cotos monásticos (Barros Guimerans 2009: 141). Es evidente que, para examinar estos espacios, se hace necesaria una precisa delimitación del territorio que se acota y, en ocasiones, esta información es inaccesible ${ }^{13}$. De la documentación analizada se puede apreciar que en tres ocasiones los cotos primigenios se extendieron a través de una red parroquial hoy en día existente ${ }^{14}$, asimismo, dos coincidieron con actuales términos municipales ${ }^{15} \mathrm{e}$, incluso, dos se constituyeron en un territorio que ahora se podría calificar de intermunicipal ${ }^{16}$ e interprovincial ${ }^{17}$. Mención especial debido a su extensa superficie merece el coto del monasterio de Celanova que agrupó en su demarcación de 14.584 hectáreas a los actuales ayuntamientos orensanos de Celanova, Verea, A Bola y Ramirás (Andrade Cernadas 1997: 164).
La fisonomía del espacio acotado no se distanciaría mucho del modelo clásico de explotación señorial, conservando un núcleo donde el cenobio ocupaba la posición predominante junto con las pertinentes edificaciones para el almacenamiento y trasformación de los diferentes productos y los terrenos agrícolas y forestales orientados a cubrir las inmediatas necesidades de los monjes (Pallares Méndez y Portela Silva 1971: 108-110). Es este entorno, y no otro, el máximo exponente de la función política en el seno del señorío monástico dentro de un esquema trifuncional que se completa, junto con la red de granjas y las edificaciones propias del monasterio, como representaciones últimas de su proyección económica y religiosa (Pallares Méndez y Portela Silva 2015: 137).

Siervos, conversos, criados asalariados y campesinos que labraban heredades cedidas por el monasterio fueron los encargados de trabajar estas reservas dominicales (Fortún Pérez de Ciriza 2002: 212). Al margen de este espacio rector se hallaban las diversas unidades de hábitat y explotación, ya fuesen estas villas, casales o simples heredades sobre las que recaían los derechos dominicales y jurisdiccionales del monasterio. Pero fue más allá de los límites de estos términos donde la búsqueda de un amparo que el campesinado ya sólo podía obtener a través de una red clientelar no hizo más que menoscabar, aún más si cabía, una autoridad real ya de por sí muy debilitada, apuntalando de esta manera la feudalización del territorio (Mínguez 1994: 166). Es en este momento, cuando adquirieron protagonismo en tierras gallegas, la incomuniación y la profiliación, instrumentos jurídicos por los que el señor pudo participar, como un miembro de la familia más, de una propiedad hasta entonces

13 Bien porque no se especifican las lindes del coto (Dozón; Fernández de Viana y Vieites 2009: doc. 30), bien porque dicho documento no se ha podido encontrar (Melón), o bien porque la colección diplomática omite cualquier referencia al mismo (San Clodio; Lucas Álvarez, Lucas Domínguez 1996a: 137).

14 Así, al coto de Pombeiro le correspondería la actual feligresía del mismo nombre, además de la vecina de Frontón y la mitad sur de la de Acedre (Lucas Álvarez y Lucas Domínguez 1996b: doc. 7); el de Moraime coincidiría con la actual parroquia del mismo nombre (Benlloch del Río y Pensado 2015: 12-13); el de Bóveda se extendería por las parroquias de San Paio de Bóveda y Santa Baia de Beiro (Fernández Fernández 2005: 40).

15 Dentro de esta categoría se incluyen San Estevo de Ribas de Sil (Nogueira de Ramuín; Duro Peña 1977: 218) y San Martiño de Xubia (Narón) según se desprende de los límites fijados para su espacio acotado en 1169 por Fernando II (Montero Díaz 1935: doc. 82).

16 Así el coto de Caaveiro ocuparía parte del municipio de A Capela además de una serie de feligresías dispersas por los ayuntamientos circundantes de Monfero, Pontedeume y Fene (Yáñez Rodríguez 2015: II, 235).

17 Es el caso del coto de Oseira que comprendía una extensión de terreno indeterminada ubicada entre el extremo nororiental de la comarca de Carballiño, el suroriental del actual partido judicial de Lalín y el suroccidental de la comarca de Chantada (Romaní Martínez 1989: doc. 15). 
circunscrita a los lazos de sangre propios de la comunidad de aldea (Isla Frez 1992: 228234), circunstancia ésta que posibilitó la desintegración de la misma y, por tanto, la caída en una relación de dependencia del campesino respecto al señor (Barbero de Aguilera 1991: 401-404).

\section{La sujeción a la tierra}

El estatus del campesino en la tierra inmune, fuese coto o villa dotada de tal privilegio, quedó condicionada por una diversidad terminológica cuyos matices diferenciadores son difíciles de precisar. De esta manera, siervos, libertos, ingenuos y serviciales, a pesar de sus distintas denominaciones, compartieron una categoría común de dependencia personal y económica, una sumisión que, en los casos pertinentes, limitaba su condición de hombres dotados de plena libertad al negárseles una mínima autonomía de movimientos (Isla Frez 1992: 203-214). Hay que tener en cuenta que el término servi en su acepción clásica-latina referida a los esclavos, si bien empezó a menguar a partir del siglo $\mathrm{X}$ aún perduraría, aunque de forma residual, hasta el XII (Fernández Ferreiro 2010: 45) y, como bienes muebles que eran, aparecieron en los fondos altomedievales como porción inalienable de aquellas enajenaciones en beneficio de ciertas entidades monásticas $\mathrm{y}$, en consecuencia, como parte intrínseca de sus patrimonios (Andrade Cernadas 1997: 141-148) ${ }^{18}$. Claro ejemplo de lo expuesto es observable en la donación efectuada por Froila Pérez en 1095 al monasterio de Moraime de una serie de villas junto con sus habitantes (familias enteras con su progenie) para que sirviesen como ingenui y no servi (Benlloch del Río, Velo Pensado 2015: 1619). Esta concepción de individuo-posesión transcendió de la condición de esclavo a la de hombre libre al aparecer ambos indistintamente adscritos a propiedades sujetas a donación ${ }^{19}$. Libertos y, especialmente, los hijos de estos, ingenuos, vieron de esta manera restringida su capacidad decisoria al continuar adscritos a la tierra y sujetos a los mismos servicios y rentas de antaño, cultivando ahora las tierras como colonos perpetuos o tributarios (Sánchez Albornoz 1976: 347-350) quienes, a su vez, tampoco se libraron de compartir el mismo destino que el de la propiedad bajo la que se hallaban circunscritos ${ }^{20}$. Otro término recurrente en la documentación del periodo es el relativo a los hombres de criazón, locución del todo polisémica que parece referirse indistintamente tanto a los esclavos y su progenitura como a los dependientes y arrendatarios libres (siervos en el sentido más tópico del medioevo; Fernández Ferreiro 2010: 61-62 y 66). Durante los siglos $\mathrm{X}$ y XI, criato designaba tanto a siervos como a libertos que, constituyendo un mismo lote junto con tierras y propiedades, fueron objeto de donación al monasterio de Samos (Lucas Álvarez 1986: docs. 6, 80, 127). En esta última centuria semejante práctica se extendería a los ingenuos, unidos en un mismo grupo con el resto de la criatione, al compartir con estos, la obligación de prestar servicio en la villa de Lusario, cedida por el monasterio de Sobrado dos Monxes al de Aranga (Pallares Méndez 1979: doc. 15). Incluso ya superada la segunda mitad del siglo XII se puede observar a serviciales (campesinos dependientes; Isla Frez 1992: 207), formando parte de los bienes que, en virtud de mandas testamentarias, son cedidos al monasterio de San Miguel de Bóveda con el fin de aumentar su patrimonio (Fernández Fernández 2005: doc. 3). Es evidente por lo manifestado hasta aquí que la adscripción a la tierra fue una imposición que trascendió la condición jurídica del individuo. Este argumento parece consolidarse en 1114 fecha en la que Visclavara Froilaz dona al monasterio de Xubia omnes homines... tam de criatione quam de uassallia (Montero Díaz 1935: 71-72), es decir que, vasallos dependientes, pese a haber nacidos libres, gozaron del mismo nulo albedrío que el de aquellos siervos de criazón nacidos ya en dependencia. Fue en este mismo periodo cuando toma forma la predisposición del inmunista relativa a fijar a los vasallos en los cotos jurisdiccionales bajo la pena de destierro

18 De hecho, uno de los rasgos definitorios de servidumbre, es aquel que hace objeto a sus miembros de venta o donación, independientemente si tal enajenación va acompañada, o no, de propiedades rústicas (Martínez Díez 1965: 84-85).

19 Loscertales de G. Valdeavellano 1976: doc. 278; Andrade Cernadas 1995: doc. 105; Loscertales de G. Valdeavellano 1976: doc. 265; Lucas Álvarez 1986: doc. 106; Loscertales de G. Valdeavellano 1976: doc. 10.

20 Como refleja la donación efectuada por Ordoño II en 914 a la catedral de Mondoñedo de cuarenta hombres tributarios (Sánchez Belda 1953: doc. 25). 
y pérdida de la mitad de las posesiones en caso de abandonarlo con el fin de servir a otro señor. Por otro lado, la tajante prohibición referida a ausentarse del coto aún se consideraba vigente para aquellos de condición más servil (Fernández de Viana y Vieites 1997: 313-315).

Con el declive de la servidumbre clásica y el paulatino triunfo de la explotación indirecta se inició un largo proceso de evolución del contrato foral, que no completaría su formulación definitiva hasta finales de la Edad Media (Ríos Rodríguez 1993a: 39) y, cuyo fin último, fue siempre la prolongación del poder jurisdiccional monástico más allá de los límites físicos del coto (Pallares Méndez 1978: 224 y 225) o, en otras palabras, la fusión de los privilegios derivados de la propiedad y de la jurisdicción en un mismo contrato. El foro pronto se instituyó como el vehículo transmisor por excelencia de los derechos señoriales, desde la segunda mitad del siglo XIII hasta los albores de la Edad Moderna, como se colige en el aforamiento de varias propiedades otorgado en 1486 por San Vicente de Pino, en el que se explicita que el forero, independientemente de que habitase o no en el coto monástico, se habría de regir por los usos y costumbres del mismo (Rodríguez Fernández 1991: doc. 389).

Una exigencia señorial, poco estudiada por la historiografía gallega, pero no por ello exenta de presencia documental es la que hace referencia a la sujeción del vasallo a la tierra ya en época foral. El instrumento propiciatorio de tal imposición es el propio foro que, como ya se ha acentuado, constituyó el vehículo más adecuado para la transmisión y extensión de las obligaciones señoriales originarias de los cotos al resto del campesinado. Es bien sabido que, uno de los mayores objetivos de los rectores del señorío fue el de mantener unos moradores estables en el seno de los núcleos de población y explotación (López Sabatel 2006: 297). Este propósito subyacía en las cláusulas forales que impelían al campesino a morar y poblar, o hacer morar y poblar por él mismo o por otro los casales aforados (Rodríguez Fernández 1991: 317; Lucas Álvarez y Lucas Domínguez 1996b: doc. 60). Íntimamente ligada a esta última disposición se hallaba la expresa prohibición impuesta al forero de enajenar el foro, sin licencia del monasterio, en beneficio de quien no compartiese su condición vasallática (Ríos Rodríguez 1993a: 230), o incluso de quien habitase fuera del coto (Rodríguez Fernández 1991: doc. 312), es decir, que el cambio de residencia del dependiente solamente era posible en la medida en que dicha libertad de movimientos no supusiera en modo alguno un perjuicio para el señor en relación con sus derechos sobre los hombres y la tierra (Martín 1982: 31, 39 y 45). Es de esta manera como los señores pudieron garantizar en provecho propio que los núcleos de población y explotación, con indiferencia de quien fuese el vasallo, siempre estuviesen habitados y explotados sin peligro de menoscabar su capacidad generadora de renta fiscal.

La prohibición de abandonar el coto monástico sin licencia quizás sea la expresión máxima de una adscripción a la tierra que excede el primigenio interés señorial orientado a satisfacer la ocupación efectiva y permanente del suelo, con independencia de quién fuese el vasallo capacitado para tal fin. Este modelo de sujeción pura aparece como práctica común en los foros de Celanova a modo de disposición final por la que el abandono del señorío conllevaba irremisiblemente la revocación del foro y la restitución de los bienes aforados de vuelta al monasterio (Vaquero Díaz 2004: docs. 175, 176, 178, 186, 188, 190, etc.). La obligación de residir dentro de los términos jurisdiccionales no se extinguía con la muerte del campesino-vasallo ya que, en ocasiones, este se ve "invitado" a recibir sepultura en el monasterio, pudiéndose constatar, al menos en lo que respecta a finales del siglo XII y principios del XIII, la existencia de una "remensa" de ultratumba o post-mortem ${ }^{21}$, al igual que acontecía en tierras castellano-leonesas (Martín 1982: 39-47).

${ }^{21}$ Uos uero et generacione uestra sitis uasali de monasterio Palumbarii in uita uestra; ad mortem uero uestram ueniatis ad sepulturam, tam uso quam generacionem uestram ad monasterium predictum... et ad obitum uestrum sepultura uestra sit in nostro monasterio... (Lucas Álvarez y Lucas Domínguez 1996a: doc. 13); ...sitis nostri uassalli de abbate et fratribus huius monasterii et sepultura uestra sit in ipso monasterio... (Ibid.: doc. 20); ... deinde sitis inde nostri uassalli et familiares, et sepultura uestra sit in nostro monasterio... (Ibid.: doc. 29); ... in vita et in morte et etiam in sepultura quam in monasterio Melonis habere debetis... (Cambón Suárez 1957). Disponible en el Corpus Documentale Latinum Gallaeciae (CODOLGA), versión 15 (2018), http://corpus.cirp.es/codolga [consulta: $18 / 11 / 2019]$. 


\section{La jurisdicción y el foro}

Como anteriormente ya se mencionó el señorío floreció de la conciliación entre la propiedad individual y la potestad jurisdiccional en el seno de los mismos espacios de poder. Una armonización que, ante las incertidumbres e inseguridades de la época, se consideró necesaria para consolidar así tanto el dominio de las explotaciones como su productividad. De este modo, gobierno de los hombres y derechos dominicales se entrelazaron para garantizar la extracción de renta (Clavero 1975: 116), lo que de algún modo explicaría el incesante desinterés de los fondos monásticos por diferenciar la propiedad del señorío, al considerar todas las rentas, independientemente de su origen, como un conjunto homogéneo e indivisible por derecho. Tal distinción se hace del todo inviable en la alta Edad Media ya que el término hacer servitium es el que impera para precisar cualquier tipo de obligación a satisfacer (Isla Frez 2002: 214). En contadas ocasiones, a mediados del siglo XI el "servicio" compartió su emplazamiento preeminente como prestación con otras imposiciones como la facendera ${ }^{22}$ o el censum ${ }^{23}$, la primera de ellas de marcado carácter jurisdiccional. En 1151 aparecen el forum y el servitium ambos como deberes ineludibles a cumplimentar por todos los hombres del $\operatorname{coto}^{24}$. En 1214, la misma fórmula reaparece otra vez como pago conjunto, erigiéndose asimismo en el distintivo por el que se achacaba al morador de una heredad aforada dentro del espacio acotado su condición de vasallo. Estas dos obligaciones quedaron incorporadas en una pesquisa real efectuada por Alfonso IX que reconocía ciertas prerrogativas inalienables de Santo Estevo de Ribas de Sil dentro de su $\operatorname{coto}^{25}$. En consecuencia, al recogerse tales prestaciones junto con el resto de las atribuciones inmunistas, no es aventurado afirmar que servicio y foro compartieron en el conceptualismo señorial una misma naturaleza jurisdiccional que se personificaba en la adquisición de la totalidad de las rentas. De hecho, una de las interpretaciones más plausibles que explican el origen del término foro para designar al contrato agrario por excelencia en tierras gallegas es aquella que lo hace derivar del vocablo forum referido al censo a satisfacer por el dependiente a su señor dentro de la jurisdicción de este último (Ríos Rodríguez 1993a: 144; Martínez Martínez 2003-2004: 254-255). No fue hasta 1238 cuando se registra en la documentación del monasterio de Melón la primera evidencia del vocablo foro para definir de manera constante la cesión contractual del dominio útil de un bien (Ríos Rodríguez 1993a: 144).

A partir del siglo XII el modelo de servidumbre polisémica "antigua" esclavo-siervo tiende a desaparecer, proceso que culmina en 1219, fecha límite, tras la cual, desaparece de la documentación de los tumbos de Sobrado cualquier mención relativa a los siervos (Pallares Méndez y Portela Silva 2007: 77). Fue casi un siglo antes, en 1114, cuando, como se vio en el apartado anterior, comenzó a utilizarse el término uasallus que definiría al campesino dependiente a lo largo de toda la Edad Media. Una de las explicaciones más recurrentes a este fenómeno habría que hallarla en el progresivo aumento del peso específico de la explotación indirecta frente a la directa, proceso mediante el cual, los hombres de criazón, sujetos en un principio a la reserva monástica, paulatinamente $\mathrm{y}$, a medida que fue cobrando protagonismo la cesión de tenencias a censo por parte de los diferentes monasterios, se irían confundiendo jurídicamente con el resto del campesinado dependiente (Andrade Cernadas 1997: 146-148). Estas concesiones, hundieron sus raíces en las "cartas de precaria" que, de origen visigodo y naturaleza enfitéutica, abrirían el camino de la explotación de un territorio allende de la limitación territorial del coto señorial a través de la adquisición de rentas campesinas (Mariño Veiras 1983: 176). De esta manera, tales instituciones contractuales altomedievales, además de constituir un factor clave en la formación

22 ingenuiti; concedimus eos cum omni sua fetutione ut omne seruitium uel facendaria que soliti fuerunt facere ad Locum Sanctum... (Lucas Álvarez 2003: 171-173).

23 et ibi faciebant seruitium et reddebant censum... (Fernández Catón 1990: 219 y 220).

24 quod homines qui ipso cauto morati fuerint, totum forum et servitium quod inde facere debent semper ipsi monasterio faciant, et alii... (Fernández de Viana y Vieites, González Balasch y de Pablos Ramírez 1997: 313-315).

25 ...quod monasterium Sancti Stephani et suum cautum stet in eo foro et in eo iure quod habuerunt a tempore avi mei imperatoris et quod per istam exquisan adquisierunt, videlicet, quod nullus sit ausus facere casam in cauto suo, nec comparare ibi hereditatem, nec homines qui morantur in hereditatibus forariis dicto monasterio forum et servicium facientes recipere in vassallos... (Duro Peña 1977: doc. 12). 
y evolución del foro (Ríos Rodríguez 1993a: 42), se erigirían en el más inmediato antecedente de los diferentes tipos de prestimonios, que bajo dos de sus vertientes (praestimonium dato y commutativo), fueron instrumentos básicos, junto con los foros, en el incremento de las propiedades monásticas (Ríos Rodríguez 1993b: 197-202). El triunfo de la explotación indirecta y la omnipresencia de los contratos agrarios en la documentación posibilitaron que se llegase a un modelo teórico que discerniese ciertas diferencias entre aquellas rentas derivadas de la propiedad cedida en usufructo (las estrictamente económicas) y aquellas prestaciones que poco tenían que ver con la explotación de la tierra y mucho con el reconocimiento del señorío. Esta distinción se hallaba en las cláusulas de obligado cumplimiento por las que el forero se había de comprometer al pago de determinados servicios y tributos debidos a su propia condición de vasallo respecto al forista, es decir, una renta más que compensatoria, generada por la obediencia exigida por el propietario-señor al receptor del contrato foral (Álvarez Álvarez 1983: 117; Pallares Méndez 1978: 224). Este modelo teórico es utilizado para facilitar el desglose y análisis histórico de las rentas señoriales gallegas, pero no por ello hay que olvidar la siempre presente dificultad a la hora de precisar una formulación categórica que supere la confusión generada por la supuesta renta señorial-jurisdiccional no sólo debido al nulo cometido de esta en el ejercicio del poder público, sino por la imposibilidad, en ocasiones, de poder desvincular algunas de estas exigencias de su naturaleza propietaria-económica. A fin de cuentas, el foro supone la cesión de una tierra sujeta a detracciones en especie o numerario y, siendo este y no otro su fin máximo, no muestra ninguna preocupación por hacer constar todo aquello relativo al empleo de las funciones jurisdiccionales del señor (Ríos Rodríguez 1993a: 84). En coherencia con lo referido, no es de extrañar que el esquema metodológico empleado por parte de la historiografía con el fin de facilitar una aproximación a los diferentes tipos de rentas y prestaciones en la Galicia medieval, sea el que viene enunciado en los contratos forales: en primer término, el correspondiente a una renta derivada de la estricta productividad del dominio útil $\mathrm{y}$, en segundo $\mathrm{y}$, el que interesa en este artículo, aquel procedente de la relación de obediencia debida por el vasallo hacia su señor.

\section{Obligaciones jurisdiccionales: servicio, foro, derechura, luctuosa}

Más arriba ya se indicó que foros y servicios compaginaron su existencia desde mediados del siglo XII bajo la modalidad de detracciones conjuntas y absolutas que no sólo recaían sobre todos los habitantes del coto, sino que, a través de su imposición y consiguiente retribución, definían la condición de vasallos de estos. Con el triunfo de la explotación indirecta a lo largo del siglo XIII ambas obligaciones quedaron relegadas a un plano más simbólico $\mathrm{o}$, si se quiere, secundario, pero conservando una naturaleza inherente al reconocimiento de señorío de tiempos precedentes. Una prestación comprendida en el grupo categorial del servicio es la que hacía referencia a la obligación por parte del vasallo de facilitar a su señor alimento y albergue cada vez que le fuese a visitar (Rodríguez Fernández 1991: doc. 242). Esta acepción fue tan común en la documentación gallega medieval que Villa-amil y Castro, en su estudio de los foros de Galicia, llegó a otorgar al servicio y al yantar el mismo significado (Villa-Amil y Castro 1884: 95-96). Por último, no es inusual la presencia de la fórmula et daredes de o por seruiço, excluyéndose de este modo cualquier tipo de especificación relacionada con la naturaleza de dicha prestación. Bien es posible que este tipo de servicio no fuese más que la conmutación en especie y dinero de una antigua prestación laboral, pero también es probable que su significación se origine en el reconocimiento público de señorío que hubo de mostrar el forero a su señor por medio de una visita anual siempre acompañada de una serie de viandas entre las que no podía faltar el pan, la carne y el vino (Lucas Álvarez y Lucas Domínguez 1996a: 181). El obsequio, por parte del vasallo de un cerdo, con su pan y vino, el día de San Andrés, constituyó el procedimiento corriente de satisfacer una fórmula de sojuzgamiento que hundía sus raíces en la alta Edad Media, periodo en el que los términos obsequium y servitium fueron usados para denominar las obligaciones del encomendado (Barbero de Aguilera y Vigil 1991: 170). La escasez de referencias nominales de este tipo de derecho señorial en los contratos forales se puede explicar por la aparente dispensabilidad del requisito concerniente a su expresión escrita; ya que no era infrecuente que la renta y plazo de entrega típicas de tal detracción se estableciesen según el uso y costumbre de la tierra, del coto, o del monasterio, sin que este último considerase necesario la inclusión del 
término "servicio" en el diploma ${ }^{26}$. Estrechamente vinculada con esta detracción se sitúa la obligación del forero de honrar la fiesta patronal de los distintos monasterios con una boa vianda o con daquello que teverdes. Estamos ante un acto de romería que comportó una significación implícita de sometimiento, fidelidad y respeto hacia el prior y el convento (Lucas Álvarez y Lucas Domínguez 1996b: doc. 45).

Anteriormente se hizo mención a la significación del forum como mecanismo recaudador en el seno de espacios acotados. Al empezar a extenderse los dominios señoriales por medio de la adquisición de propiedades fuera de dichos espacios, este término empezó a designar al conjunto de rentas que recibía el señor-propietario, tanto como resultado de la cesión del dominio útil como en reconocimiento de señorío. Es por ello por lo que, al igual que en León, en Galicia se pueden establecer ciertas similitudes entre esta figura jurídica y la infurción castellana, al ser ambas instituciones máximas expresiones de dependencia territorial y señorial (Sebastián Amarilla 1999: 313). En este sentido, para la mayoría de los autores, la infurción no fue más que el pago por el reconocimiento del dominio eminente del suelo que satisface el cultivador de tierra ajena o el que habita el solar del señor (Morán Martín 1992: 96). Es más, a partir de la recepción del derecho común se empezó a dar el nombre de infurción a los censos que el poseedor del dominio útil había de pagar a su señor. En consecuencia, en este proceso de asimilación terminológica no resultó extraña la voz foro, en la mayoría de los casos idéntica a la de infurción, desarrollándose una unificación semántica que llegaría a completarse en el siglo XVI (Morán Martín 1993: 177-182). No fue hasta bien entrado el siglo XIII, y bajo una coyuntura tendente a incrementar el poder jurisdiccional sobre los dependientes, cuando se empezó a diferenciar dentro del contrato foral una renta recognoscitiva de dicho poder, también denominada foro o derechura (Ríos Rodríguez 1993a: 142-145), exacción esta que empezó a identificarse claramente con la sumisión del forero al dominio señorial en el ámbito de las rentas señoriales propias de la documentación foral (Fernández Fernández 2005: 45).

Quizá la renta señorial más peculiar de tierras gallegas fuera la luctuosa, una tasa relacionada con la intervención señorial en las sucesiones que consistía en el derecho del señor a cobrar un canon tras la muerte del forero titular para que pudiera heredar el foro su o sus sucesores (Lucas Álvarez y Lucas Domínguez 1996b: doc. 38). Aquí se advierte una vinculación de naturaleza jurisdiccional entre esta prestación y la anteriormente mencionada "remensa de ultratumba" en el sentido en que, según se extrae de un foro otorgado en 1277 por la abadesa del monasterio de San Pedro de Vilanova de Dozón, el forero debía ser vasallo del monasterio tanto en vida como en la muerte, alegato que justificaría plenamente la exigencia de dicha carga mortuoria ${ }^{27}$. Esta detracción, al igual que sucedía con el nuncio en Castilla, era predominantemente monetaria, siendo demandada como reminiscencia de una forma más antigua de la carga (una pieza de ganado) y de su doble significación como modelo de pago y como elemento de estratificación social (Clemente Ramos 1986: 74 y 79). Sin embargo, en el dominio de Santa María de Oseira, aunque indirectamente, aún en 1359 se pudo asociar a la luctuosa con reses, al quedar la posible exigencia de la misma supeditada a la capacidad o incapacidad del forero tras su óbito para haber dejado los casales aforados poblados con bueyes y vacas ${ }^{28}$. En todos los casos en los que aparece la luctuosa, los bienes cedidos en usufructo estuvieron constituidos por unidades de poblamiento y explotación (lugares, casales o casares) y, en función del valor de estos espacios y de la condición del receptor del foro, se determinaba la cuantía del canon a satisfacer. Esta tasa, con relativa frecuencia, al igual que sucedía con la derechura, estuvo sujeta a un incremento proporcional al orden de las voces que se sucediesen en el foro. Parece evidente, llegados a este punto, que la luctuosa, si bien nominalmente se reclamó por razón de señorío, pragmáticamente su función

26 Claro ejemplo de lo expuesto se puede hallar en estos cinco documentos pertenecientes a la colección diplomática del monasterio de Pombeiro (Lucas Álvarez y Lucas Domínguez 1996b: docs. 102, 153, 185, 221, 247).

27 ...et ille homo qui habitaverit in illo debet ese noster vassallus in vita et in morte. Et primus istorum trium qui hobierit debet dare unum morabetinum pro luctuosa, et secundum X solidos, et tercius XV solidos, et sint de ista moneta blanca vel per quantitatem illius... (Fernández de Viana y Vieites 2009: doc. 63).

28 ... a o finamento de cada hun de vos daredes por loytosa viinte moravedis de dineyros brancos non avendo en os ditos casares bois ou vacas.... (Romaní Martínez et al. 1999: doc. 1755). 
siempre anduvo encaminada a garantizar unos ingresos extraeconómicos adheridos e inherentes a la unidad de producción aforada, independientemente de quién labrase las tierras ${ }^{29}$.

\section{La Justicia}

Uno de los privilegios de coto cedidos por el monarca a las entidades eclesiásticas fue el relativo al ejercicio de la justicia en el seno de estos espacios. En época de Alfonso VII la generalización de estos beneficios llevó consigo una concesión tácita de esta prerrogativa, usualmente bajo fórmulas tales como cum tuto suo directo, cum tuto suo foro et suo directo o sicut ad regale ius pertinet (Moxó Ortiz de Villajos 2000: 145). No obstante, existen referencias mucho más explícitas anteriores a su reinado relativas a este derecho otorgado. De este modo, entre los años 1027 y 1047 tanto la catedral de Lugo como los monasterios de Celanova y San Antolín se vieron dotados con privilegios reales que les otorgaban plena jurisdicción sobre delitos relativos al homicidio y rapto (Sánchez Belda 1953: docs. 137, 160; Andrade Cernadas 1995: docs. 6 y 29). Sin embargo, a partir de la segunda mitad de la siguiente centuria se empezaron a limitar tales prerrogativas dentro de una política real dirigida a recuperar de alguna manera parte de la autoridad monárquica (Álvarez Castrillón 2007: 155). Teniendo esto en mente, no es de extrañar que en 1214 los delitos de rapto, latrocinio, traición y quebrantamiento de camino, en lo que al coto de Santo Estevo de Ribas de Sil se refiere, pasasen a ser competencia de la potestad del rey representado por su merino (Duro Peña 1977: doc. 11). En 1229 Alfonso IX también se reservaría en Tierra de Caldelas el derecho a juzgar, además de los delitos anteriormente citados, el de violación (Pastor de Togneri et al. 1990: 322).

Si bien los procedimientos penales, como es lógico, tuvieron que recaer en la esfera jurisdiccional de los distintos monasterios gallegos, poco o nada se sabe de ellos debido al silencio de las fuentes. Así, en la documentación del señorío de Meira, por poner un ejemplo, sólo se testimonia el interés del abad en reservarse para sí mismo la prerrogativa de dirimir las causas criminales (Mariño Veiras 1983: 112).
Esta inclinación por ejercer la administración de justicia no era de extrañar, teniendo en consideración el nexo existente entre esta función y el cobro de multas judiciales o caloñas cuya cuantía fijaba el propio señor (Álvarez Borge 2003: 55). Tales sanciones de carácter general solían diferenciarse de otras penalizaciones que tomaban el nombre de aquellos delitos sobre los que estos privilegios de coto gravaban, en especial, los relativos al homicidio, rapto y hurto (Pérez Rodríguez 2004: docs. 5 y 50). Una práctica que parece confirmar un continuismo jurisprudencial en comunión con la resolución de los procesos penales que, siguiendo la doctrina legal del Liber Iudiciorum, castigaba compensatoriamente y pecuniariamente todo tipo de delitos (Mínguez 1997: 528-535). Dicha línea de procedimiento se explica por la relativa y parcial pervivencia hasta al menos el siglo XIII del antiguo derecho godo dentro del ecléctico ordenamiento legal en toda la península ibérica (Gacto Fernández, García Marín y Alejandre 1988: 190-197). De manera que no sorprenden en el tumbo de Celanova para el siglo $\mathrm{X}$ las resoluciones de los procesos criminales asociadas a la fijación de reparaciones económicas hacia las partes agraviadas tanto por homicidio en 940 (Sáez y Sáez 1996: doc. 64) y 963 (Andrade Cernadas 1995: doc. 165) como por complicidad en adulterio en 952 (Ibid.: doc. 96) o robo en 961 (Ibid.: doc. 141).

Esta preferencia del dinero sobre el encarcelamiento fue recurrente en el derecho medieval peninsular como demuestra el escaso protagonismo dentro del procedimiento judicial dado a la prisión cautelar en contraposición con la más común exigencia de prenda o fianza como garante de la presencia del acusado ante el tribunal (Ramos Vázquez 2008: 39-56). A fin de cuentas, las ventajas de esta línea de actuación procesal frente al encarcelamiento no dejaban de ser obvias: por un lado, se obtenía cierto respaldo encaminado a favorecer la asistencia del inculpado ante los jueces de la manera menos onerosa y más sencilla posible para la administración de la justicia y por el otro, en caso de incomparecencia o huida del demandado, dicho aval quedaba disponible para su reparto entre el señor, sus oficiales y el agraviado en concepto de retribución ${ }^{30}$. De

\footnotetext{
29 ...Et se y morar por vos outro home que page a nos o loytosa por lo seu quando morrer... (Romaní Martínez et al. 1999: doc. 1578).

30 Véanse los estudios clásicos sobre este tema realizados por Orlandis Rovira 1942-43 y 1953.
} 
este modo, en 931, la huida de un condenado a pagar treinta bueyes por el delito de hurto impuso a sus fiadores el pago de veinte de estos animales a la parte agraviada, lo que a su vez propició la cesión por parte de los progenitores del prófugo de todas sus propiedades a dichos fiadores (Pallares Méndez 1979: doc. 2). A su vez, más al sur, en 975, Astrario perdía una heredad en favor del monasterio de Celanova a causa del incumplimiento de deuda de su cuñado (Andrade Cernadas 1995: doc. 368).

No obstante, no hay duda de que, en vista de los testimonios que han sobrevivido hasta nuestros días, hablar de justicia monástica medieval es hablar de procedimientos "civiles" más preocupados en resolver disputas y precisar responsabilidades, que en castigar al presunto infractor de la norma. Por todo ello es comprensible que se extendiese el arbitraje y ulterior avenencia como mecanismos elegidos en la resolución de conflictos (Gacto Fernández, García Marín y Alejandre 1988: 198). Esto se refleja en 959 en el compromiso alcanzado por cinco familias de Santa Eulalia de Lemos de ceder la cuarta parte de la producción de unas tierras que no tenían derecho a cultivar al monasterio de San Pedro, dependiente de Celanova y propietario dominical de las mismas (Andrade Cernadas 1995: doc. 446).

El proceso, como es obvio, comenzaba con la elección de jueces que, en un principio, se constituían en una especie de comisión sumarial dotada a su vez de capacidad decisoria. Un hecho diferencial propio de tierras gallegas fue el número de estos jueces, mucho mayor que en la meseta castellana, siendo su principal labor determinar y fijar las diferentes fases que debían de estructurar todo el proceso (Davies 2016: 237). Un grupo de once de estos jueces-árbitros también conocidos por turba non modica se encargó de resolver uno de los primeros pleitos entre el monasterio de Celanova y ciertos miembros de su entorno señorial. Fue en 987 cuando los vecinos de la villa de Zacoys reclamaron para sí la titularidad de la vilulla de San Fiz, resultando la demanda en una resolución favorable al monasterio (Andrade Cernadas 1995: doc. 94). Este proceso se organizó en los siguientes estadios ${ }^{31}$ : promesa por los representantes de ambas partes de presentarse ante los jueces y de aceptar la resolución judicial; el pactum o evacuatio, es decir, la confesión y sometimiento de la parte perdedora; un manifestum por separado a modo de sumisión del portavoz de los demandantes; la renuncia del bien en litigio y su entrega por parte del sayón al monasterio como parte ganadora.

Al ser el juramento parte esencial del proceso no fue de extrañar que los tribunales se constituyesen en recintos eclesiásticos, iglesias o los propios monasterios, a fin de dotar a los votos y testimonios de una más alta jerarquía en cuanto a su ritualidad y sacralidad ${ }^{32}$.

En 1063 Celanova de nuevo se vería inmerso en un juicio, esta vez en defensa de la jurisdicción de unas tierras que un considerable número de habitantes de ciertas villas sitas en la comarca de Limia consideraban ingenuas. De modo que el rey Fernando I nombró un juez ante el cual los representantes de Celanova debían aportar pruebas escritas que favoreciesen su causa. Estas, asimismo, tenían que estar respaldadas por el juramento de cinco filii multorum benenatorum quienes, tras un oportuno examen sobre el terreno, determinaron que, si bien no todas, una buena parte de las propiedades en cuestión quedaban bajo mandación del monasterio (Andrade Cernadas 1995: 300). Queda aquí patente una constante en la fase probatoria de los procesos correspondientes a disputas sobre la propiedad: la importancia, no sólo de poseer escrituras, sino de corroborarlas con testimonios jurados cuya veracidad siempre podía ser impugnada por la parte contraria (Collins 1986: 86). Este sistema testifical se apreció a finales del siglo XIII, en la forma de conciliación tras saber la verdad per homees boos et per previlegioz et per cartas (Vaquero Díaz 2004: doc. 90).

El proceso más común junto al interpuesto para determinar al propietario, fue el desarrollado con el fin de delimitar posesiones, esto es, el de fijar la demarcación de las mismas. En 1110 el pleito entre Celanova y los hombres de Castrelo por esclarecer los límites de dicha villa

31 Un orden cronológico en el texto que según Roger Collins no corresponde a la evolución del proceso en sí, sino más bien, a una tardía compilación de las cinco partes distintas del pleito realizada a posteriori por un inexperto escriba. El fin de estas compilaciones estribaba en el interés de los monasterios de asegurarse copias de los acuerdos sobre renuncias de propiedades (Collins 1986: 90).

32 Sobrado y Celanova fueron recurrentes anfitriones de estas asambleas judiciales (Andrade Cernadas 2018: 21-25). 
junto con los de Seixadas y Rubiás se resolvió a favor del primero gracias a los testimonios sobre los sacramentos ante los jueces; bastó el juramento del abad y de sus hombres ante las tres reiteradas negativas a acometer tal formalidad por los vecinos de la villa en cuestión (Andrade Cernadas 1995: doc. 105). Aquí, como en los casos precedentes se aprecia la gran importancia que conllevaba en el proceso medieval el sacramentum tanto de testigos como de las partes. Un acto solemne dirigido, no tanto a sustentar la fiabilidad y el buen carácter de los pleiteantes, sino más bien a arrojar luz sobre los hechos inherentes a la materia juzgada (Davies 2016: 42-43). No obstante, en lo concerniente a pleitos por lindes fue de gran significación la labor de los "hombres buenos", recorriendo los campos, recopilando declaraciones de los más ancianos del lugar y, actuando como agrimensores en busca y restauración de perdidos u ocultos marcos divisorios (Collins 1986: 88). Una función judicial, en todas sus facetas, que se caracterizó por una intermitente continuidad a lo largo de toda la época medieval, como se colige en el contencioso de 1481 entre Celanova y el concejo de la misma localidad sobre el deber o no de sus vecinos de pagar luctuosa al monasterio. Aquí se puede apreciar las tres fases del proceso para esta época tan tardía: en primer lugar, la elección de tres hombres buenos (uno representando a cada parte, pudiéndose elegir como tercero al alcalde mayor del reino de Galicia, siempre y cuando los dos anteriores no alcanzasen un acuerdo); en segundo, un largo interrogatorio-pesquisa bajo juramento sobre los santos evangelios al que se somete a los testigos y conducido por dichos jueces-árbitros; para finalizar con una sentencia dictada unánimemente por los hombres buenos designados por ambas partes en presencia y con conformidad del representante de rey (Vaquero Díaz 2004: docs. 716, 717 y 718).

La elección llevada a cabo por los pleiteantes de sus propios árbitros $\mathrm{u}$ hombres buenos para dirimir sus disputas, ya fuese en su condición de parte fundamental de la fase probatoria o como jueces (o realizando ambas funciones al unísono) no resulta ni mucho menos insólita en la documentación monástica del siglo XIII. De hecho, en 1262, una cláusula integrada en el foro de un casal emitido por el monasterio de Oseira prevé una posible querella por parte del forero y otorga quince días para su resolución tras previa revisión y dictamen de bonorum hominum (Romaní Martínez 1989: doc. 898$)^{33}$. En 1285, se establece en un documento emitido por Santo Estevo de Ribas de Sil las fases de un procedimiento sobre la pertenencia de cierto patrimonio entre el monasterio y un particular: las partes elegirán a un canónigo como juez árbitro y este, a su vez, sustentará su decisión en el testimonio jurado de hombres buenos previamente designados (Duro Peña 1977: doc. 57). Veintinueve años después la propiedad de una parcela en Lebosende se convirtió en objeto de disputa entre el monasterio de San Clodio y una familia de la vecindad; ambos litigantes tuvieron derecho a escoger jueces árbitros quienes realizaron una pesquisa entre los habitantes de Leiro y, tras ella, aconsejados por hombres buenos sentenciaron a favor del monasterio, compeliendo a la parte perdedora a pagar foro por los frutos del terreno en litigio (Lucas Álvarez y Lucas Domínguez 1996a: doc. 285).

No obstante, hay que recordar que, pese a lo arriba expuesto, hubo entidades monásticas que se mostraron proclives a someter los procesos legales en sus cotos al arbitrio de jueces de su libre designación, aferrándose, de esta manera, a sus prerrogativas jurisdiccionales. No hay que olvidar que el estudio de los enjuiciamientos en pleno medioevo siempre ha de tener presente una carencia de la uniformidad esperada en los mismos explicable por la conocida ausencia de una regulación sistemática del ordenamiento jurídico (Sánchez-Arcilla Bernal 2002: 43). De este modo Fernando IV en 1307 se vio obligado a ratificar los privilegios judiciales de Celanova ante la pretensión del concejo de Milmanda de poner juez y notario en el coto de Vestiaría. De manera que todo habitante de dicho coto a partir de ese momento no tuvo más remedio que librar sus pleitos y formalizar sus cartas y escrituras ante los jueces y notarios designados por el monasterio (Vaquero Díaz 2004: I, doc. 100). Esta figura, en el siglo XIV correspondía a la de un administrador quien, con el apoyo de omnes leterados et sabedores, dictaba sentencia siempre y cuando el demandante y el demandado fuesen vasallos del monasterio (Ibid.: doc. 152).

33 La elección de jueces u hombres buenos por las partes también aparece en la colección diplomática de este monasterio con anterioridad en los documentos 495 y 664 . 


\section{Conclusiones}

El primer asunto que hay que abordar en este apartado es el concerniente a la estrecha consonancia existente entre el dominio señorial y la propiedad dominical. Si bien, en un principio, las potestades jurisdiccionales emanaron de cesiones realizadas por el monarca, con el triunfo de la explotación indirecta y, en consecuencia, la universalización del contrato foral, tales prerrogativas resultaron fuertemente enraizadas en la propiedad de la tierra. De este modo, el señorío derivado de las cesiones de derechos regios y aquel fruto de la propiedad convergieron en una única realidad. Se puede afirmar, por consiguiente, que no se puede entender el ejercicio de ciertas potestades jurisdiccionales si estas no se apoyan en el dominio eminente de la tierra. Tal aseveración puede explicar la abundancia de casos en los que la documentación muestra propiedades de un monasterio enclavadas en los espacios acotados de otros. Parece evidente que la cesión en un momento determinado de un mero dominio señorial no tenía porqué cambiar el estatuto jurídico de todo un territorio específico si esta transmisión no venía acompañada de las suficientes propiedades regias como para hacerlo.

Lo hasta aquí argumentado explica que, a partir del siglo XIII, las prestaciones denominadas jurisdiccionales se pudiesen calificar así más en la medida en que nada tenían que ver con las detracciones económicas ejercidas sobre la producción que en su labor primigenia de desempeño de la autoridad pública. Adoptando la perspectiva señorial, la confusión relativa a la verdadera naturaleza de la renta señorial resultaba del todo indiferente, teniendo en consideración la percepción imperante de la misma como un todo uniforme, a la vez que heterogéneo, sujeta a ser satisfecha en contraprestación por el usufructo del bien aforado. La inclinación señorial por explotar, asegurar y extender su patrimonio, no solamente fue evidente por su interés en la sujeción del campesinado a las zonas de cultivo, sino también, por su uso de la administración de justicia. El empleo de esta función de carácter público fue el crisol en el que se fundieron dos tendencias de la época encontradas: por un lado, la participación de los rectores monásticos en las disputas sobre la propiedad y demarcaciones en beneficio propio; por el otro la plena consciencia de propiedad y disposición del campesinado para unirse con el fin de luchar por lo que consideraban suyo por derecho. No obstante, y, ya desde un punto de vista metodológico, ha quedado bien patente tras el examen de todos estos pleitos la ausencia de unas líneas de actuación procesal concurrentes que den uniformidad al procedimiento medieval. En consecuencia, el estudio de los diferentes modelos de enjuiciamiento, las diferentes fases dentro del mismo, así como número y categoría de sus partícipes solamente se podrá efectuar desde una aproximación individualizada y específica que atienda a cada caso de manera particular.

\section{Referencias bibliográficas}

Alfonso de Saldaña, María Isabel (1974): "Las sernas en León y Castilla. Contribución al estudio de las relaciones socio-económicas en el marco del señorío medieval”, Moneda y crédito 129, pp. 153-210.

Álvarez Álvarez, Eleutino (1983): "Las exigencias señoriales en la Galicia meridional a través de la duración y la renta de los contratos de foro (1340-1450)", Cuadernos de estudios gallegos 99, pp. 117-152.

Álvarez Borge, Ignacio (2003): La plena Edad media. Siglos XII-XIII, Madrid: Síntesis.

Álvarez Castrillón, José Antonio (2007): La comarca de los Oscos en la Edad Media. Poblamiento, economía y poder. Oviedo: KRK Ediciones.

Andrade Cernadas, José Miguel (1995): O Tombo de Celanova: estudio introductorio, edición e índices (SS. IX-XII). Santiago de Compostela: Consello da Cultura Galega.

(1997): El monacato benedictino y la sociedad de la Galicia medieval (siglos X al XIII). Sada: Edicios do Castro.

(2007): "La implantación del monasterio en la sociedad: Celanova", en J. Á. García de Cortázar y R. Teja (coords): Los grandes monasterios benedictinos hispanos de época románica: (1050-1200). Aguilar de Campoo: Fundación Santa María la Real, pp. 121-140.

(2012): "La voz de los ancianos. La intervención de los viejos en los pleitos y disputas en la Galicia medieval", Hispania: Revista española de historia 242, pp. 11-34.

(2018): "Baños, claustros y piedras: una aproximación a los escenarios de las asambleas judiciales en la Galicia altomedieval", Studia historica. Historia medieval 36, pp. 13-30.

Arias Cuenllas, Maximino (1992): Historia del monasterio de San Julián de Samos. Zamora: Monasterio de Samos / Diputación Provincial de Lugo. 
Barbero de Aguilera, Abilio y Marcelo Vigil (1991): La formación del feudalismo en la Península Ibérica. Barcelona: Crítica.

Barrau-Dihigo, Louis (1919): "Etude sur les actes des rois asturiens (718-910)", Revue Hispanique 46, pp. 1-192.

Barros Guimerans, Carlos (2009): “Origen del castillo y coto de Aranga, siglos X-XII”, Cuadernos de estudios gallegos 122, pp. 139-150, https://doi.org/10.3989/ceg.2009.v56.i122.59.

Beceiro Pita, Isabel (1977): La rebelión irmandiña. Madrid: Akal.

Benlloch del Río, José Enrique; Ismael Velo Pensado (2015): “La documentación medieval del priorato de Moraime (I)", Nalgures 11, pp. 11-79, http://www.estudioshistoricos.com/wp-content/uploads/2014/10/ Nalgures-XI-Moraime-medieval.pdf.

Bermúdez Beloso, Mariña (2017): O espazo do occidente peninsular e a súa organización territorial: ca. 700-ca. 1250. Tesis doctoral inédita. Santiago de Compostela: Universidade de Santiago de Compostela.

- (2017): "Presares: comitatum, commisso, territorio? Dimensión documental e espacial dun topónimo abandonado", Cuadernos de estudios gallegos 132, pp. 77-105.

Cambón Suárez, Segundo (1957): El monasterio de Santa María de Melón (siglos XII-XIII). Tesis doctoral inédita. Santiago de Compostela: Universidad de Santiago de Compostela.

Clavero, Bartolomé (1975): "Señorío y hacienda a finales del antiguo régimen en Castilla. A propósito de recientes publicaciones", Moneda y Crédito 135, pp. 111-128.

Clemente Ramos, Julián (1986): "Mañería y nuncio en el Becerro de las Behetrías", Norba. Revista de historia 7, pp. 71-80.

Colás Latorre, Gregorio (1993): "La historiografía sobre el señorío tardofeudal”, en E. Serrano Martín y E. Sarasa Sánchez (eds.): Señorío y feudalismo en la Península Ibérica (ss. XII-XIX). Zaragoza: Institución Fernando el Católico, vol. 1, pp. 51-105.

Collins, Roger (1986): "Visigothic law and regional custom in disputes in early medieval Spain", en W. Davies y P. Fouracre (eds.): The Settlement of Disputes in Early Medieval Europe. Cambridge: Cambridge University Press, pp. 85-104.

Corpus Documentale Latinum Gallaeciae (CODOLGA), versión 15 (2018). Santiago de Compostela: Centro Ramón Piñeiro para a Investigación en Humanidades, http://corpus.cirp.es/codolga.

Davies, Wendy (2016): Windows on Justice in Northern Iberia, 800-1000. Abingdon: Routledge.

Deaño Gamallo, Carlos Alberto (2004): Ribadavia y su comarca en la Baja Edad Media. Sada: Ediciós do Castro.

Díaz Salvado, María Elena (2011): Falsos y falsificaciones en documentación latina medieval del Reino de León. Tesis doctoral inédita. Santiago de Compostela: Universidade de Santiago de Compostela.

Duro Peña, Emilio (1977): El monasterio de San Esteban de Ribas de Sil. Ourense: Instituto de Estudios Orensanos "Padre Feijoo".

Fernández Casal, Miguel Ángel (1995): "Relaciones de poder Monarquía-Iglesia en la época medieval: las concesiones regias de cotos a la catedral de Orense (s. XII-XIII)", Minius 4, pp. 71-88.

Fernández Catón, José María (1990): "El llamado Tumbo Colorado y otros códices de la iglesia compostelana: ensayo de reconstrucción", Archivos Leoneses 87-88, pp. 7-292.

Fernández de Viana y Vieites, José Ignacio (2009): Colección diplomática do mosteiro de San Pedro de Vilanova de Dozón. Santiago de Compostela: Consello da cultura galega.

Fernández de Viana y Vieites, José Ignacio; María Teresa González Balasch y Juan Carlos de Pablos Ramírez (1996): "El tumbo de Caaveiro", Cátedra: revista eumesa de estudios 3, pp. 267-437.

(1997): "El tumbo de Caaveiro", Cátedra: revista eumesa de estudios 4, pp. 221-385.

Fernández Fernández, Adolfo (2005): O Mosteiro feminino de San Miguel de Bóveda na Idade Media. Estudo histórico e colección documental (séculos XII-XV). Noia: Toxosoutos.

Fernández Ferreiro, Marcos (2010): Servos e escravos altomedievais no noroeste da Península Ibérica. Noia: Toxosoutos.

Fortún Pérez de Ciriza, Luis Javier (2002): "El señorío monástico altomedieval como espacio de poder", en J. I. de la Iglesia Duarte y J. L. Martín Rodríguez (coords.): Los espacios de poder en la España medieval: XII Semana de Estudios Medievales (Nájera, del 30 de julio al 3 de agosto de 2001). Logroño: Instituto de Estudios Riojanos, pp. 181-243.

Freire Camaniel, José (1998): El monacato gallego en la Alta Edad Media. A Coruña: Fundación Pedro Barrié de la Maza, 2 vols. 
Gacto Fernández, Enrique; José María García Marín y Juan Antonio Alejandre (1988): El derecho histórico de los pueblos de España: (temas y textos para un curso de historia del derecho). Madrid: AGISA.

García de Valdeavellano, Luis (2000): El feudalismo hispánico y otros estudios de historia medieval. Barcelona: Crítica.

García Álvarez, Manuel-Ruben (1973): “De Calogo a San Martín pasando por Corticela?”, Compostellanum 18, pp. 251-284.

González Vázquez, Marta (1991): "El dominio del monasterio de San Julián de Samos en siglo XIV (13251380)", Cuadernos de estudios gallegos 104, pp. 95-112.

Isla Frez, Amancio (1992): La sociedad gallega en la Alta Edad Media. Madrid: CSIC. (2002): La alta Edad Media. Siglos VIII-XI. Madrid: Síntesis.

López Carreira, Anselmo (ed.) (2008): O Condado de Lemos na Idade Media. I Simposio de Historia en Terra de Lemos. Ourense: Xunta de Galicia.

López Sabatel, José Antonio (2006): “Aproximación al suelo habitable en la Ribeira Sacra durante los siglos XIV y XV”, Espacio, Tiempo y Forma. Serie III 19, pp. 293-303, https://doi.org/10.5944/ etfiii.19.2006.3759.

López Sabatel, José Antonio (2007): "Cultivos agrícolas en la Ribeira Sacra durante los siglos XIV y XV", Espacio, Tiempo y Forma. Serie III 20, pp. 183-198, https://doi.org/10.5944/etfiii.20.2007.3763.

López-Salas, Estefanía (2017): "El papel del clero regular en la ordenación del paisaje. El caso del monasterio de San Julián de Samos", Hispania sacra 139, pp. 19-29.

López Sangil, José Luis (2006): "Un nuevo documento de 1117 del monasterio de Caaveiro", Cátedra: revista eumesa de estudios 13, pp. 165-188.

Loscertales de G. Valdeavellano, Pilar (1976): Tumbos del monasterio de Sobrado de los Monjes. Madrid: Dirección General del Patrimonio Artístico y Cultural, Archivo Histórico Nacional, 2 vols.

Lucas Álvarez, Manuel (1986): El Tumbo de San Julián de Samos (siglos VII-XII): Estudio introductorio. Edición diplomática. Apéndices e índices. Santiago de Compostela: Caixa Galicia.

Lucas Álvarez, Manuel (2003): El Monasterio de San Martiño Pinario de Santiago de Compostela en la Edad Media. Sada: Ediciós do Castro.

Lucas Álvarez, Manuel y Pedro Lucas Domínguez (1996a): El monasterio de San Clodio do Ribeiro en la Edad Media: Estudio y documentos. Sada: Ediciós do Castro.

(1996b): El priorato benedictino de San Vicenzo de Pombeiro y su colección diplomática en la Edad Media. Sada: Ediciós do Castro.

Mariño Veiras, Dolores (1983): Señorío de Santa María de Meira (De 1150 a 1525). Espacio rural, régimen de propiedad y régimen de explotación en la Galicia medieval. A Coruña: Nós.

Martín, José Luis (1982): “¿Campesinos de remensa en Castilla y León? (siglos XII y XIII)”, En la España Medieval 3, pp. 37-48.

Martínez Díez, Gonzalo (1965): "Las instituciones del reino astur a través de los diplomas (718-910)", Anuario de historia del derecho español 35, pp. 59-168.

Martínez García, Luis (2008): "Jurisdicción, propiedad y señorío en el espacio castellano del Camino de Santiago (ss. XI y XII)", Hispania 228, pp. 11-36, https://doi.org/10.3989/hispania.2008.v68.i228.73.

Martínez Martínez, Faustino (2003-04): "De Verborum Significatione: notas sobre las acepciones medievales de la voz foro", Boletín do Museo Provincial de Lugo 11, pp. 247-264.

Mínguez, José María (1994): Las sociedades feudales. 1. Antecedentes, formación y expansión (siglos VI al XIII). Madrid: Nerea.

(1997): "Justicia y poder en el marco de la feudalización de la sociedad leonesa", en La giustizia nell alto Medioevo (Secoli IX-XI), Spoleto 1997, Settimane di studio del Centro italiano di studio sull Alto Medioevo. Spoleto: Centro italiano di studi sull'alto Medioevo, pp. 491-548.

Mitre Fernández, Emilio (2006): Historia de la Edad Media en Occidente. Madrid: Cátedra.

Montero Díaz, Santiago (1935): "Colección diplomática de San Martín de Jubia", Boletín de la Universidad de Santiago 25, pp. 3-156.

Morán Martín, Remedios (1992): "Naturaleza jurídica de la infurción. I: Concepto y evolución”, Boletín de la Facultad de Derecho de la UNED 2, pp. 77-108.

- (1993): "Naturaleza jurídica de la infurción. II: Figuras afines y evolución hasta el siglo XVI", Boletín de la Facultad de Derecho de la UNED 3, pp. 153-199.

Moxó y Ortiz de Villajos, Salvador de (2000): Feudalismo, señorío y nobleza en la Castilla medieval. Madrid: Real Academia de la Historia. 
Orlandis Rovira, José (1942-43): "La prenda como procedimiento coactivo en nuestro derecho altomedieval (Notas para su estudio)", Anuario de Historia del Derecho Español 14.

(1953): "La prenda de iniciación del juicio en los fueros de la familia Cuenca-Teruel", Anuario de Historia del Derecho Español 23.

(1964): "Las congregaciones monásticas en la tradición suevo-gótica", Anuario de Estudios Medievales 1, pp. 97-119.

Pallares Méndez, María del Carmen (1978): "Los cotos como marco de los derechos feudales en Galicia durante la Edad Media (1100-1500)", Liceo Franciscano 31, pp. 201-225.

(1979): El Monasterio de Sobrado: un ejemplo del protagonismo monástico en la Galicia medieval. A Coruña: Deputación Provincial da Coruña.

Pallares Méndez, María del Carmen y Ermelindo Portela Silva (1971): El Bajo Valle del Miño en los siglos XII y XIII. Economía agraria y estructura social. Santiago de Compostela: Universidade de Santiago de Composela.

(2007): "El lugar de los campesinos. De repobladores a repoblados", en A. Rodríguez (coord.): El lugar del campesino en torno a la obra de Reyna Pastor. Valencia: CSIC, pp. 61-88.

- (2015): "Para una lectura histórica del paisaje. La impronta medieval”, en G. Pereira Menaut y E. Portela Silva (eds.): El territorio en la historia de Galicia: organización y control, siglos I-XXI. Santiago de Compostela: Universidade de Santiago de Compostela, Servizo de Publicacións e Intercambio Científico, pp. 97-152.

Pastor de Togneri, Reyna; Ana Rodríguez López, María Isabel Alfonso Antón y Pablo Sánchez León (1990): Poder monástico y grupos domésticos en la Galicia foral (siglos XIII-XV). La Casa. La Comunidad. Madrid: CSIC.

Pérez Rodríguez, Francisco Javier (1996): O mosteiro de Melón no século XV. Ourense: Deputación de Ourense.

(2004): O mosteiro dos Santos Xusto e Pastor de Toxosoutos na Idade Media (séculos XII-XIII). Sada: Ediciós do Castro.

(2004): Os documentos do tombo de Toxos Outos (1038-1334). Santiago de Compostela: Consello da Cultura Galega.

- (2008a): "Historia medieval de Galicia: un balance historiográfico (1988-2008)", Minius 18, pp. $59-146$.

(2008b): Mosteiros de Galicia na Idade Media. Ourense: Deputación provincial de Ourense.

Pérez Rodríguez, Francisco Javier; María Beatriz Vaquero Díaz y Mercedes Durany Castrillo (2002) “A Terra de Celanova na Idade Media", Minius 10, pp. 143-158.

Portela Silva, Ermelindo (1976): La Región del obispado de Tuy en los siglos XII a XV. Una sociedad en la expansión y en la crisis. Santiago de Compostela: El Eco Franciscano.

- (2009): "El rey y los obispos: Poderes locales en el espacio galaico durante el periodo astur", en F. J. Fernández Conde y C. García de Castro Valdés (coords.): Symposium Internacional Poder y Simbología en Europa, siglos VIII-X (Actas del Symposium Internacional convocado en Oviedo, 22-27 de septiembre del 2008), Oviedo: Universidad de Oviedo, pp. 215-226.

Portela Silva, Ermelindo; María del Carmen Pallares Méndez (1993): "La investigación histórica sobre la Edad Media en Galicia", en J. G. Beramendi (coord.): Galicia e a historiografía. Santiago de Compostela: Tórculo Edicións, pp. 76-106.

Pousa Diéguez, Rodrigo (2018): “Del señorío medieval a la jurisdicción señorial en Galicia: transformaciones y cambios entre los siglos XIV y XVI", Medievalismo 28, pp. 175-202, https://doi.org/10.6018/345081.

Ramos Vázquez, Isabel (2008): Arrestos, cárceles y prisiones en los derechos históricos españoles. Madrid: Ministerio del Interior, Dirección General de Instituciones Penitenciarias.

Rassow, Peter (1928): "Die Urkunden Kaiser Alfons' VII. von Spanien. Eine palaeographisch-diplomatische Untersuchung", Archiv für Urkundenforschung 10, pp. 328-467.

Rodríguez Galdo, María Xosé (1976): Señores y campesinos en Galicia. Siglos XIV-XVI. Santiago de Compostela: Pico Sacro.

Ríos Rodríguez, María Luz (1993a): As orixes do foro na Galicia medieval. Santiago de Compostela: Universidade de Santiago de Compostela.

(1993b): "Propiedad de la tierra y relaciones señoriales: el Praestimonium en Galicia (1150-1350)", en E. Sarasa Sánchez y E. Serrano Martín (eds.): Señorío y feudalismo en la Península Ibérica (ss. XIIXIX). Zaragoza: Institución Fernando el Católico, vol. 3, pp. 197-207. 
Rodríguez Fernández, Carlos (1991): La colección diplomática de San Vicente del Pino. Tesis doctoral inédita. Granada: Universidad de Granada, 4 vols.

Romaní Martínez, Miguel (1989): Colección diplomática do mosteiro cisterciense de Sta. María de Oseira (Ourense) 1025-1310 Vol. I. Santiago de Compostela: Tórculo Edicións.

(1989): Colección diplomática do mosteiro cisterciense de Sta. María de Oseira (Ourense) 10251310 Vol. II. Santiago de Compostela: Tórculo Edicións.

Romaní Martínez, Miguel; María José Portela, María del Pilar Rodríguez Suárez y Mercedes Vázquez Bertomeu (1999): Colección diplomática do mosteiro cisterciense de Sta. María de Oseira (Ourense) 1310-1399 Vol. III. Santiago de Compostela: Tórculo Edicións.

Sáez Emilio y Carlos Sáez (1996): Colección diplomática del monasterio de Celanova (842-1230), vol. 1 (842-942). Alcalá de Henares: Universidad de Alcalá.

- (2000): Colección diplomática del monasterio de Celanova (842-1230), vol. 2 (943-988). Alcalá de Henares: Universidad de Alcalá.

Sánchez Albornoz, Claudio (1966): Despoblación y repoblación del valle del Duero. Buenos Aires: Instituto de Historia de España.

(1976): Viejos y Nuevos estudios sobre las instituciones medievales españolas. Madrid: Espasa-Calpe.

Sánchez-Arcilla Bernal, José (2002): "La administración de justicia en León y Castilla durante los siglos X al XIII", en J. de Santiago Fernández y J. M. ${ }^{a}$ de Francisco Olmos (eds.): I Jornadas sobre documentación jurídico-administrativa, económico-financiera y judicial del reino castellano-leonés (siglos $X$-XIII). Madrid: Universidad Complutense de Madrid, pp. 13-49.

Sánchez Belda, Luis (1953): Documentos reales de la Edad Media referentes a Galicia. Madrid: Servicio de publicaciones del Ministerio de Educación Nacional.

Sánchez Carrera, María del Carmen (1997): El Bajo Miño en el siglo XV. El espacio y los hombres. A Coruña: Fundación Pedro Barrié de la Maza.

Sánchez Pardo, José Carlos (2010): “Estrategias territoriales de un poder monástico en la Galicia medieval: Celanova (siglos X-XII)", Studia historica. Historia medieval 28, pp. 155-178.

Sebastián Amarilla, José Antonio (1999): "Del fuero al arrendamiento. Tenencia y explotación de la tierra en León entre la Edad Media y la Edad Moderna", Revista de Historia Económica 17, pp. 305-341.

Serra i Clota, Assumpta (1993): "Economía y sociedad a lo largo del siglo XIV en la Cataluña Central: efectos de la peste negra", en E. Sarasa Sánchez y E. Serrano Martín (eds.): Señorío y feudalismo en la Península Ibérica (ss. XII-XIX). Zaragoza: Institución Fernando el Católico, vol. 3, pp. 449-472.

Vaquero Díaz, María Beatriz (2004): Colección diplomática do Mosteiro de San Salvador de Celanova (ss. $X I I I-X V)$. Santiago de Compostela: Tórculo, 4 vols.

Vázquez, Germán (1990): Historia de Monforte y su tierra de Lemos. León: Editorial Evergráficas.

Villa-Amil y Castro, José (1884): Los foros de Galicia en la Edad Media: estudio de las transformaciones que ha sufrido en Galicia la contratación para el aprovechamiento de las tierras. Madrid: Establecimiento Tipográfico de los sucesores de Rivadeneyra, impresores de la Real Casa.

Vital Fernández, Sonia (2011): "La participación política de la nobleza gallega en el reinado de Alfonso VII (1126-1157): entre la rebelión y la lealtad al rey”, Studia historica. Historia medieval 29, pp. 99-120.

Vital Fernández, Sonia (2016): "La alta aristocracia gallega y sus estrategias en el poder ante los cambios políticos y sociales en época de Alfonso VII", Minius 24, pp. 43-75

Yáñez Rodríguez, José Manuel (2015): San Juan de Caaveiro. Un monasterio entre la naturaleza. Análisis gráfico, arquitectónico y paisajístico. A Coruña: Deputación Provincial da Coruña. 